\title{
Inference of a seismic gap from geological data: Thessaly (Central Greece) as a case study
}

\author{
Riccardo Caputo \\ Via Alberto Lollio 7, Ferrara, Italy
}

\begin{abstract}
As a result of neotectonic, morphotectonic and seismotectonic research it is now possible to draw detailed maps of the major active faults affecting Thessaly, a large region of continental Greece. For many of these faults, where specific studies have been carried out, the degree of fault activity (i.e. the long-term slip-rate) has been also assigned ranging from 0.05 to $4 \mathrm{~mm} / \mathrm{yr}^{-1}$. In the present work, the main morphotectonic features and seismotectonic characteristics of the more important faults are recalled from previous works, while the recent tectonic activity is compared with the seismic activity of the area. The occurrence of both large $(M>6.0)$ and moderate $(M \leq 6.0)$ earthquakes during the present century is concentrated in the southern sector. Earthquakes have been virtually absent in the northern part of the region during the same period. In contrast, according to geological and geomorphological criteria, the recent (Late Quaternary) tectonic evolution of the region and the overall extensional rate do not seem to differ significantly in the two sectors. Although palaeoseismological trenches, geodetic surveying and the record of the microseismic activity may enhance our knowledge of this problem, on the basis of available geological (structural and morphological) data, it is likely that the northern sector of Thessaly represents a large seismic gap. The implications on seismic hazard in one of the more populated regions of Greece are also discussed.
\end{abstract}

Key words seismic gap - morphotectonics - seismotectonics - Greece

\section{Introduction}

From the tectonic point of view, the whole Aegean region can be considered a large scale natural laboratory where many kinds of deformational environments, from plastic to brittle, from deep to shallow and from extensional to compressional, have been and are generated. As a consequence, unravelling the deformational history of the region has been a challenge for many geologists during the last four decades (Brunn, 1956; Aubouin, 1959; Celet, 1962; Dercourt, 1964; Godfriaux, 1968; Mercier, 1968; Pegoraro, 1972; Lemeille, 1977; and others).
Whilst several problems still arise for the older tectonic events, most of the scientific community feel more confident with the results of neotectonic studies. Though debates are still open on the existence of minor or local phases of deformation and their exact chronology, the state of the science on this topic indicates a tectonic stratigraphy largely accepted by specialists. In fact, all the major phases which affected the region, their relative and absolute chronology as well as the stress field trajectories have been clearly recognised for wide sectors of the Aegean region (e.g. Mercier, 1981; Mercier et al., 1979, 1987; Angelier, 1977, 1979; Pavlides and Mountrakis, 1987; Sorel, 1989; Angelier et al., 1981) including Thessaly (Caputo, 1990a). 


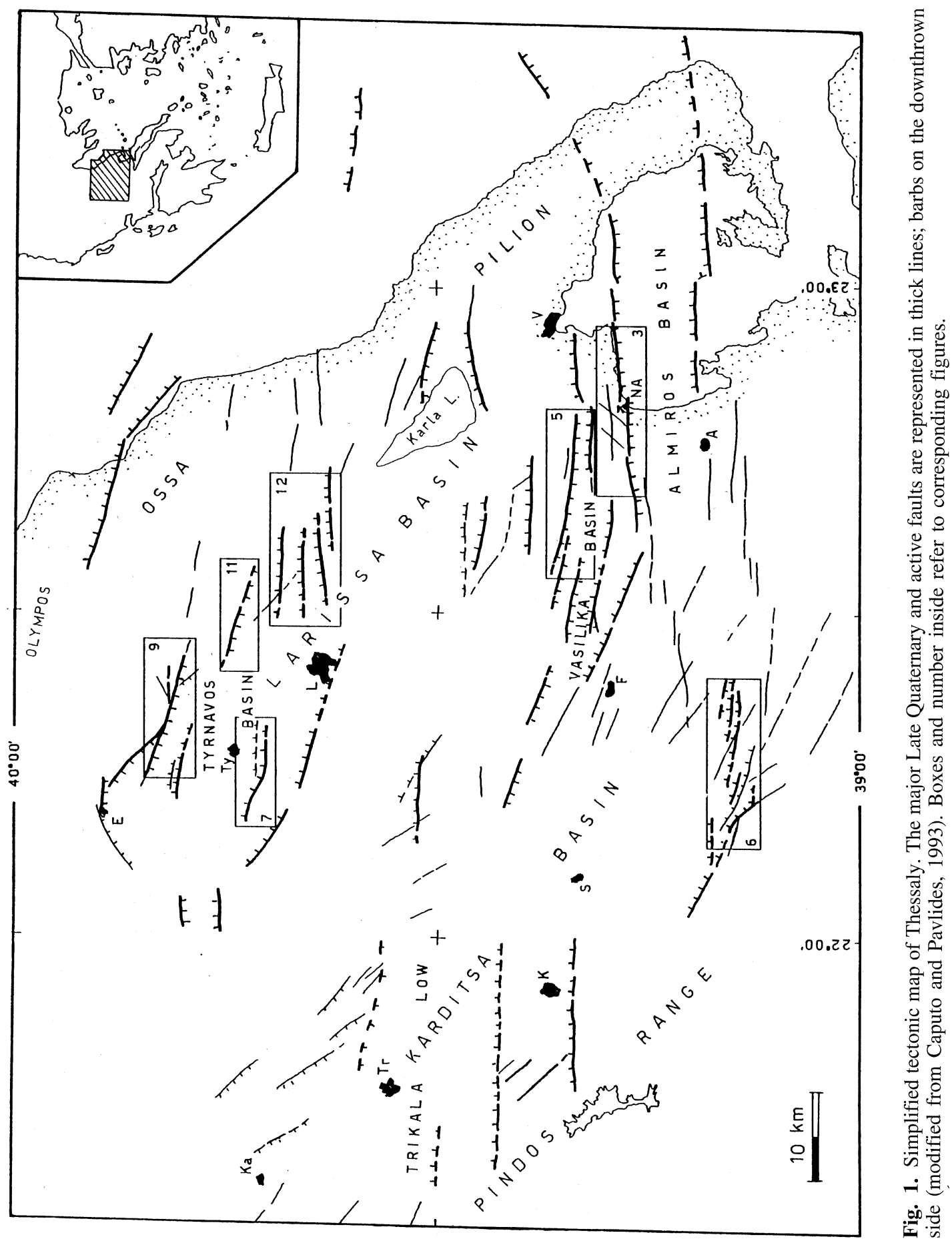


Structural mapping has been compiled for this region of continental Greece and, according to a detailed quantitative structural analysis, several tectonic phases have been distinguished since Miocene times (Caputo, 1990a). In particular, the last phase started during Middle Pleistocene and it is still active in Thessaly, where crustal deformation is characterised by pure extension, with a $\mathrm{N} 10^{\circ} \mathrm{E}$ average direction of the least principal stress axis, $\sigma_{3}$.

According to the classification suggested by the Research Group for Active Faults of Japan (RGAFJ, 1992), the degree of fault activity has been classified as class A $\left(10 \mathrm{~mm} / \mathrm{yr}^{-1}>S \geq 1\right.$ $\left.\mathrm{mm} / \mathrm{yr}^{-1}\right)$, class B $\left(1 \mathrm{~mm} / \mathrm{yr}^{-1}>S \geq 0.1\right.$ $\left.\mathrm{mm} / \mathrm{yr}^{-1}\right)$ or class C $\left(0.1 \mathrm{~mm} / \mathrm{yr}^{-1}>S \geq 0.01\right.$ $\left.\mathrm{mm} / \mathrm{yr}^{-1}\right)$.

Although the basin-and-range-like physiography of Thessaly is basically the result of the older (Oligo-Miocene) orogenic tectonism and (Pliocene-Lower Pleistocene) post-orogenic collapse (Caputo and Pavlides, 1993), the last (Middle Pleistocene-Present) tectonic phase also affected the region by generating a new system of relatively small basins with a general $\mathrm{E}-\mathrm{W}$ trend (fig. 1). This younger graben system has been superimposed onto the inherited NW-SE trending one, causing the complex blocky pattern we can see today.

The Late Quaternary stress field, as inferred from structural data for the northern Aegean region (e.g. Mercier et al., 1987; Pavlides and Mountrakis, 1987; Caputo, 1990a), is in good agreement with that estimated from focal mechanisms (e.g. Papazachos and Comninakis, 1978; Papazachos et al., 1991) and from in-situ stress measurements (Paquin et al., 1982). Unfortunately, within the studied region of Thessaly only the focal mechanisms relative to the 1980 Volos earthquakes (main, fore- and aftershocks) and the 1985 Almyros earthquake are available (Papazachos et al., 1983; Taymaz, et al., 1991) as well as a unique in-situ measurement near Pharsala (see Caputo and Pavlides, 1993, for full references and detailed analyses of all available data). The observations from both geophysical methods confirm a presentday N-S extension, while historical and instrumental records from the region show considerable seismic activity (table I).
If we take into account the epicentral distribution of the present century (fig. 2), an apparent anomaly is evident for Thessaly. In the southern sector, the seismic activity is widespread while in the northern sector it is almost completely absent. It is also important to note that both large $(M>6.0)$ and moderate $(4.0<M \leq 6.0)$ size earthquakes follow this distribution. Therefore, two possible and alternative solutions may be proposed to explain this pattern. First, a northern rigid, independent and non-deforming block exists or, second, the northern region represents a large seismic gap. It is implicit that the two contrasting solutions support very different implications and consequences. Accordingly, the evaluation of seismic hazard in one of the more populated regions of Greece would be greatly affected. The aim of the present research is to contribute to the selection of the correct solution by geological investigations.

The seismic gap hypothesis is commonly referred to segments of plate boundaries that have not ruptured in large earthquakes in many decades and which are the most likely sites of future large earthquakes (McCann et al., 1979; Sykes and Nishenko, 1984; Bolt, 1993). Thessaly is certainly not an interplate boundary. However, I suggest the same concept can be applied to any active fault where the slip rate and the recurrence time are reasonably known and an earthquake is expected to occur in the future though of moderate size.

During the last decade, a project has been undertaken to study the recent tectonic evolution of Thessaly. The programme was divided into three major steps: neotectonics, morphotectonics and palaeoseismicity. The first step has already been achieved. Complete data with results are published in specific papers (Caputo, 1990a; Caputo and Pavlides, 1993) as are data and results obtained from the morphotectonic approach (Caputo, 1990b; 1993a; 1995; Caputo et al., 1994). Indeed, the geomorphology of Thessaly is predominantly controlled by tectonic activity. Palaeoseismicity work is in progress. In the present research, to allow the analysis of the possible seismic gap in the northern part of the study area, most morphotectonic results from the above mentioned papers will be referred to. 
Table I. List of the earthquakes which occurred from 510 B.C. to 1985 in Thessaly, Central Greece. Data from Comninakis and Papazachos (1982, 1986), Papazachos and Papazachou (1989) and Ambraseys and Jackson (1990).

\begin{tabular}{|c|c|c|c|c|c|c|}
\hline \multicolumn{3}{|c|}{ Date } & Hour & Latitude (N) & Longitude (E) & $M$ \\
\hline \multicolumn{3}{|c|}{510 B.C. } & & 39.4 & 22.3 & 7.0 \\
\hline 1544 & Apr. & 22 & & 39.0 & 22.4 & 6.6 \\
\hline 1566 & Jul. & 11 & & 39.0 & 21.7 & 6.5 \\
\hline 1621 & Feb. & 24 & & 39.4 & 22.0 & 6.2 \\
\hline 1661 & Mar. & 31 & & 39.4 & 22.1 & 6.1 \\
\hline 1668 & Aug. & & & 39.6 & 22.4 & 6.2 \\
\hline 1674 & Jan. & 26 & 07: & 39.4 & 21.9 & 6.2 \\
\hline 1731 & & & & 39.6 & 22.5 & 6.0 \\
\hline 1735 & Sep. & 01 & 06: & 39.5 & 21.8 & 6.5 \\
\hline 1743 & Feb. & 12 & & 39.3 & 22.8 & 6.8 \\
\hline 1766 & Nov. & 09 & & 39.7 & 22.2 & 6.3 \\
\hline 1773 & Mar. & 16 & 08: & 39.3 & 22.7 & 6.6 \\
\hline 1781 & Aug. & 28 & & 39.6 & 22.5 & 6.3 \\
\hline 1787 & Jun. & 19 & 03: & 39.5 & 21.9 & 6.0 \\
\hline 1868 & Oct. & 03 & 23:30: & 39.2 & 23.4 & 6.3 \\
\hline 1905 & Jan. & 20 & $02: 32: 30$ & 39.6 & 23.0 & 6.0 \\
\hline 1909 & Jun. & 15 & $23: 30: 30$ & 39.1 & 22.2 & 5.7 \\
\hline 1911 & Oct. & 22 & $22: 31: 45$ & 39.5 & 23.0 & 6.0 \\
\hline 1915 & Jun. & 04 & $17: 22: 02$ & 39.1 & 21.5 & 5.8 \\
\hline 1916 & Feb. & 06 & $13: 14: 58$ & 39.2 & 23.2 & 5.0 \\
\hline 1916 & Feb. & 06 & $14: 39: 40$ & 39.1 & 23.5 & 5.8 \\
\hline 1916 & Feb. & 06 & $15: 17: 38$ & 39.1 & 23.5 & 5.0 \\
\hline 1918 & Sep. & 06 & $12: 32: 18$ & 39.0 & 21.5 & 4.9 \\
\hline 1919 & Feb. & 25 & $23: 33: 30$ & 39.3 & 23.5 & 5.3 \\
\hline 1919 & Feb. & 26 & $23: 04: 27$ & 39.3 & 23.5 & 5.0 \\
\hline 1922 & Mar. & 15 & $05: 12: 35$ & 39.3 & 22.8 & 4.9 \\
\hline 1930 & Feb. & 23 & $18: 19: 12$ & 39.5 & 23.0 & 6.0 \\
\hline 1930 & Mar. & 31 & $12: 33: 48$ & 39.5 & 23.0 & 6.1 \\
\hline 1936 & Mar. & 26 & 03:07:56 & 39.5 & 22.7 & 5.0 \\
\hline 1940 & Oct. & 21 & $22: 02: 03$ & 39.0 & 22.7 & 4.9 \\
\hline 1941 & Mar. & 01 & $03: 52: 47$ & 39.6 & 22.5 & 6.3 \\
\hline 1941 & Mar. & 01 & 07:51:08 & 39.6 & 22.5 & 5.1 \\
\hline 1941 & Mar. & & $15: 00.55$ & 39.6 & 22.5 & 4.9 \\
\hline 1941 & May & 14 & $08: 36: 21$ & 39.5 & 22.6 & 5.5 \\
\hline 1941 & May & 16 & $01: 27: 48$ & 39.5 & 22.6 & 5.3 \\
\hline 1942 & Jun. & 01 & 09:01:18 & 39.3 & 22.4 & 5.2 \\
\hline 1942 & Jun. & 01 & 09:17:40 & 39.3 & 22.4 & 5.6 \\
\hline 1942 & Jun. & 01 & $22: 10: 21$ & 39.3 & 22.4 & 5.0 \\
\hline 1951 & Jan. & 21 & 18:51:16 & 39.1 & 23.0 & 4.9 \\
\hline 1951 & May & 08 & 19:09:29 & 39.5 & 21.5 & 4.9 \\
\hline 1951 & Aug. & 24 & $15: 19: 32$ & 39.1 & 22.4 & 4.5 \\
\hline 1951 & Oct & 13 & $16: 42: 27$ & 39.0 & 23.4 & 5.3 \\
\hline 1953 & Apr. & 13 & $12: 51: 11$ & 39.0 & 22.6 & 4.8 \\
\hline 1953 & Jul. & 03 & $02: 37: 50$ & 39.2 & 23.4 & 4.8 \\
\hline 1953 & Jul. & 03 & $02: 45: 00$ & 39.2 & 23.4 & 4.7 \\
\hline 1954 & Apr. & 25 & $20: 03: 46$ & 39.3 & 22.2 & 4.6 \\
\hline 1954 & Apr. & 30 & $13: 02: 36$ & 39.3 & 22.2 & 7.0 \\
\hline 1954 & Apr. & 30 & $19: 33: 30$ & 39.3 & 22.2 & 5.1 \\
\hline
\end{tabular}


Table I (continued).

\begin{tabular}{|c|c|c|c|c|c|c|}
\hline & Date & & Hour & Latitude (N) & Longitude (E) & $M$ \\
\hline 1954 & May & 01 & $02: 41: 54$ & 39.3 & 22.2 & 4.7 \\
\hline 1954 & May & 03 & $17: 46: 11$ & 39.3 & 22.2 & 4.6 \\
\hline 1954 & May & 04 & $16: 43: 20$ & 39.3 & 22.2 & 5.6 \\
\hline 1954 & May & 04 & $16: 45: 27$ & 39.3 & 22.2 & 5.7 \\
\hline 1954 & May & 04 & $23: 44: 54$ & 39.3 & 22.2 & 5.0 \\
\hline 1954 & May & 05 & 00:58:05 & 39.3 & 22.2 & 4.6 \\
\hline 1954 & May & 05 & $02: 58: 49$ & 39.3 & 22.2 & 4.6 \\
\hline 1954 & May & 07 & $08: 33: 15$ & 39.3 & 22.2 & 4.5 \\
\hline 1954 & May & 09 & $16: 13: 02$ & 39.3 & 22.2 & 4.7 \\
\hline 1954 & May & 09 & $20: 13: 20$ & 39.3 & 22.2 & 4.6 \\
\hline 1954 & May & 16 & $15: 58: 48$ & 39.3 & 22.2 & 4.5 \\
\hline 1954 & May & 17 & $11: 17: 12$ & 39.3 & 22.2 & 4.5 \\
\hline 1954 & May & 25 & $22: 03: 32$ & 39.3 & 22.2 & 5.6 \\
\hline 1954 & May & 28 & $07: 43: 02$ & 39.3 & 22.2 & 4.9 \\
\hline 1954 & Jun. & 05 & $14: 05: 32$ & 39.3 & 22.2 & 5.0 \\
\hline 1954 & Jun. & 16 & 22:08:00 & 39.3 & 22.2 & 4.6 \\
\hline 1954 & Jul. & 09 & $23: 17: 01$ & 39.3 & 22.2 & 4.5 \\
\hline 1954 & Aug. & 05 & $03: 48: 22$ & 39.5 & 22.0 & 4.8 \\
\hline 1954 & Dec. & 02 & $18: 29: 47$ & 39.4 & 22.6 & 4.6 \\
\hline 1955 & Jan. & 03 & 01:07:03 & 39.2 & 22.1 & 5.6 \\
\hline 1955 & Jan. & 08 & 07:53:01 & 39.2 & 22.0 & 5.1 \\
\hline 1955 & Feb. & 21 & $19: 46: 44$ & 39.4 & 23.1 & 4.9 \\
\hline 1955 & Apr. & 19 & $16: 47: 19$ & 39.3 & 23.0 & 6.2 \\
\hline 1955 & Apr. & 21 & 07:18:19 & 39.3 & 23.1 & 5.8 \\
\hline 1955 & May & 13 & $19: 54: 32$ & 39.3 & 23.0 & 4.8 \\
\hline 1955 & Oct. & 09 & $14: 19: 22$ & 39.0 & 22.8 & 4.6 \\
\hline 1956 & Jan. & 21 & $09: 50: 55$ & 39.5 & 22.2 & 4.9 \\
\hline 1956 & Mar. & 13 & $20: 21: 14$ & 39.5 & 21.5 & 4.5 \\
\hline 1956 & Mar. & 26 & $22: 51: 00$ & 39.5 & 21.9 & 4.5 \\
\hline 1956 & Mar. & 28 & $11: 39: 15$ & 39.5 & 21.9 & 4.6 \\
\hline 1956 & May & 18 & $22: 08: 28$ & 39.0 & 22.8 & 5.1 \\
\hline 1956 & Jun. & 26 & $06: 27: 40$ & 39.5 & 22.2 & 5.0 \\
\hline 1956 & Nov. & 02 & $16: 04: 33$ & 39.3 & 23.1 & 5.6 \\
\hline 1957 & Mar. & 08 & $12: 14: 14$ & 39.3 & 22.7 & 6.5 \\
\hline 1957 & Mar. & 08 & $12: 21: 13$ & 39.3 & 22.6 & 6.8 \\
\hline 1957 & Mar. & 08 & $12: 54: 06$ & 39.3 & 22.7 & 4.9 \\
\hline 1957 & Mar. & 08 & $20: 30: 40$ & 39.3 & 22.7 & 4.5 \\
\hline 1957 & Mar. & 08 & $20: 37: 57$ & 39.3 & 23.0 & 5.4 \\
\hline 1957 & Mar. & 08 & $23: 35: 09$ & 39.2 & 22.8 & 6.0 \\
\hline 1957 & Mar. & 09 & 04:01:42 & 39.3 & 22.6 & 4.7 \\
\hline 1957 & Mar. & 09 & $10: 29: 36$ & 39.3 & 22.7 & 4.5 \\
\hline 1957 & Mar. & 11 & $07: 19: 14$ & 39.3 & 22.7 & 4.6 \\
\hline 1957 & Mar. & 11 & $09: 31: 14$ & 39.3 & 22.7 & 5.2 \\
\hline 1957 & Mar. & 11 & $13: 26: 50$ & 39.3 & 22.7 & 4.7 \\
\hline 1957 & Mar. & 11 & 13:39:36 & 39.3 & 22.6 & 5.2 \\
\hline 1957 & Mar. & 24 & $06: 24: 07$ & 39.6 & 22.9 & 4.7 \\
\hline 1957 & Mar. & 26 & $23: 23: 30$ & 39.3 & 22.7 & 4.6 \\
\hline 1957 & Mar. & 28 & $22: 26: 01$ & 39.3 & 22.7 & 5.5 \\
\hline 1957 & May & 12 & $07: 52: 31$ & 39.3 & 22.7 & 4.8 \\
\hline 1957 & May & 13 & $06: 34: 33$ & 39.4 & 22.6 & 4.7 \\
\hline
\end{tabular}


Table I (continued).

\begin{tabular}{|c|c|c|c|c|c|c|}
\hline & Date & & Hour & Latitude (N) & Longitude (E) & $M$ \\
\hline 1957 & May & 21 & $13: 24: 18$ & 39.4 & 22.8 & 5.6 \\
\hline 1957 & Jun. & 27 & $07: 10: 55$ & 39.4 & 22.7 & 4.8 \\
\hline 1957 & Jul. & 13 & $03: 31: 41$ & 39.4 & 22.7 & 4.6 \\
\hline 1957 & Sep. & 17 & $21: 10: 30$ & 39.5 & 23.0 & 4.6 \\
\hline 1957 & Sep. & 20 & $02: 19: 24$ & 39.5 & 23.0 & 4.9 \\
\hline 1957 & Sep. & 21 & $16: 50: 22$ & 39.5 & 23.0 & 4.6 \\
\hline 1957 & Oct. & 24 & $22: 45: 10$ & 39.4 & 23.1 & 4.5 \\
\hline 1957 & Oct. & 25 & $02: 18: 33$ & 39.4 & 23.1 & 4.5 \\
\hline 1957 & Nov. & 27 & 03:08:04 & 39.2 & 22.6 & 5.6 \\
\hline 1959 & Apr. & 25 & $09: 31: 00$ & 39.5 & 22.8 & 4.7 \\
\hline 1959 & May & 14 & $00: 55: 54$ & 39.8 & 23.3 & 4.5 \\
\hline 1960 & Jun. & 03 & 02:31:06 & 39.0 & 23.2 & 4.5 \\
\hline 1961 & Jan. & 28 & $07: 18: 16$ & 39.4 & 22.0 & 4.9 \\
\hline 1962 & Sep. & 24 & $23: 30: 10$ & 39.3 & 22.0 & 4.7 \\
\hline 1965 & Jun. & 03 & $18: 31: 51$ & 39.7 & 23.2 & 5.0 \\
\hline 1966 & Feb. & 05 & $02: 01: 45$ & 39.1 & 21.7 & 6.2 \\
\hline 1966 & Feb. & 05 & 02:11:08 & 39.2 & 21.9 & 5.0 \\
\hline 1966 & Feb. & 05 & 02:58:01 & 39.1 & 21.9 & 5.3 \\
\hline 1966 & Oct. & 21 & $16: 17: 04$ & 39.5 & 22.1 & 4.7 \\
\hline 1966 & May & 04 & $04: 46: 19$ & 39.5 & 21.5 & 4.5 \\
\hline 1966 & May & 04 & $13: 13: 36$ & 39.8 & 21.5 & 4.5 \\
\hline 1966 & May & 04 & $13: 31: 08$ & 39.6 & 21.3 & 4.8 \\
\hline 1966 & May & 05 & $06: 26: 38$ & 39.6 & 21.5 & 4.7 \\
\hline 1966 & May & 09 & $08: 0: 47$ & 39.7 & 21.4 & 4.6 \\
\hline 1969 & Feb. & 21 & $18: 39: 57$ & 39.1 & 21.9 & 4.6 \\
\hline 1969 & May & 16 & $07: 27: 01$ & 39.1 & 21.8 & 5.2 \\
\hline 1971 & Jun. & 20 & 02:04:07 & 39.1 & 21.8 & 4.5 \\
\hline 1975 & Apr. & 18 & $20: 59: 10$ & 39.0 & 23.4 & 4.5 \\
\hline 1976 & Feb. & 22 & $12: 02: 53$ & 39.4 & 22.1 & 5.2 \\
\hline 1976 & Feb. & 22 & $22: 01: 49$ & 39.4 & 22.1 & 4.8 \\
\hline 1976 & Feb. & 22 & $22: 54: 35$ & 39.4 & 22.1 & 4.8 \\
\hline 1976 & Aug. & 19 & $22: 36: 25$ & 39.1 & 22.1 & 4.5 \\
\hline 1977 & Apr. & 05 & $17: 15: 09$ & 39.3 & 23.3 & 4.5 \\
\hline 1977 & May & 13 & $18: 17: 44$ & 39.1 & 23.5 & 5.0 \\
\hline 1978 & Jan. & 31 & 06:39:19 & 39.3 & 22.9 & 4.6 \\
\hline 1979 & Feb. & 07 & $10: 16: 48$ & 39.6 & 23.3 & 4.7 \\
\hline 1979 & Jun. & 21 & 02:09:53 & 39.6 & 22.2 & 4.5 \\
\hline 1980 & Jan. & 21 & $07: 47: 03$ & 39.3 & 22.9 & 4.7 \\
\hline 1980 & Jan. & 25 & $23: 08: 15$ & 39.2 & 23.0 & 4.5 \\
\hline 1980 & Jul. & 04 & $20: 20: 16$ & 39.3 & 22.9 & 4.9 \\
\hline 1980 & Jul. & 05 & $05: 34: 37$ & 39.2 & 23.0 & 4.5 \\
\hline 1980 & Jul. & 05 & 08:06:10 & 39.3 & 22.9 & 4.5 \\
\hline 1980 & Jul. & 06 & $05: 34: 43$ & 39.2 & 22.9 & 5.1 \\
\hline 1980 & Jul. & 07 & $16: 04: 42$ & 39.3 & 22.9 & 4.9 \\
\hline 1980 & Jul. & 08 & 02:59:31 & 39.2 & 22.9 & 4.6 \\
\hline 1980 & Jul. & 09 & 02:10:20 & 39.3 & 22.9 & 5.4 \\
\hline 1980 & Jul. & 09 & 02:11:57 & 39.3 & 22.9 & 6.5 \\
\hline 1980 & Jul. & 09 & $02: 35: 52$ & 39.2 & 22.6 & 6.1 \\
\hline 1980 & Jul. & 09 & $06: 01: 48$ & 39.3 & 22.9 & 5.1 \\
\hline 1980 & Jul. & 09 & $06: 11: 07$ & 39.2 & 23.0 & 4.5 \\
\hline
\end{tabular}


Table I (continued).

\begin{tabular}{ccccccc}
\hline \hline & Date & & Hour & Latitude $(\mathrm{N})$ & Longitude (E) & $M$ \\
\hline 1980 & Jul. & 09 & $16: 06: 01$ & 39.2 & 22.9 & 4.5 \\
1980 & Jul. & 10 & $19: 39: 03$ & 39.3 & 22.9 & 5.4 \\
1980 & Jul. & 15 & $00: 31: 42$ & 39.3 & 23.1 & 4.7 \\
1980 & Jul. & 15 & $11: 34: 54$ & 39.3 & 23.1 & 4.8 \\
1980 & Jul. & 16 & $00: 06: 59$ & 39.3 & 22.6 & 5.0 \\
1980 & Jul. & 24 & $10: 44: 12$ & 39.3 & 23.0 & 4.7 \\
1980 & Jul. & 29 & $20: 41: 31$ & 39.3 & 23.0 & 5.0 \\
1980 & Aug. & 11 & $09: 16: 00$ & 39.3 & 22.7 & 5.3 \\
1980 & Aug. & 12 & $01: 41: 06$ & 39.3 & 22.7 & 4.8 \\
1980 & Sep. & 26 & $04: 19: 21$ & 39.3 & 22.8 & 4.8 \\
1980 & Oct. & 21 & $02: 35: 43$ & 39.3 & 23.0 & 4.6 \\
1980 & Oct. & 21 & $04: 07: 18$ & 39.3 & 23.0 & 4.8 \\
1981 & May & 06 & $00: 18: 25$ & 39.3 & 22.8 & 4.8 \\
1982 & Aug. & 05 & $11: 05: 44$ & 39.3 & 23.0 & 4.6 \\
1984 & Dec. & 07 & $00: 09: 24$ & 39.3 & 22.9 & 4.5 \\
1984 & Dec. & 15 & $09: 01: 22$ & 39.9 & 22.7 & 4.8 \\
1985 & Apr. & 30 & $18: 14: 13$ & 39.3 & 22.8 & 5.8 \\
1985 & Sep. & 21 & $10: 13: 11$ & 39.0 & 22.3 & 4.8 \\
\hline
\end{tabular}

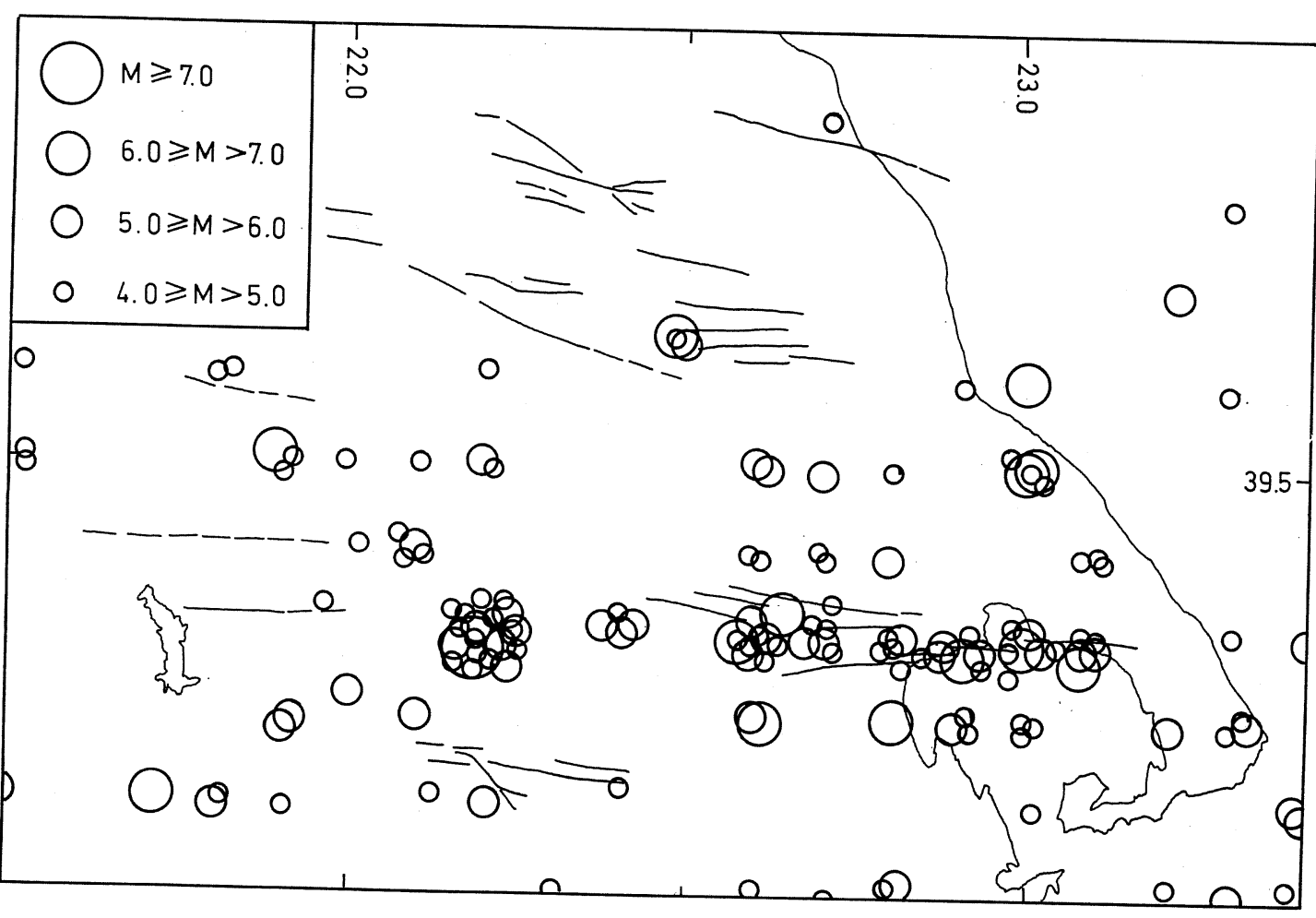

Fig. 2. Map of the epicentral distribution of Central Greece for the period 1901-1985 (from Comninakis and Papazachos, 1986). The major active faults of Thessaly, have been simplified from fig. 1. 


\section{Late Quaternary faulting}

While for the first neotectonic investigations, geological and structural mapping was undertaken to identify and map all major and minor tectonic structures affecting the area, the next step was to detect and separate all faults generated and activated during the last (Middle Pleistocene-Present) tectonic phase (fig. 1). In particular, special care was taken for all faults showing features of very recent activity. In order to understand their geometry and kinematics in detail, a different specific approach was employed. The morphotectonic survey of all these structures was carried out using maps at the scale 1:5000, and aerial photographs at the scale 1:33000.

Most of the faults generated during the Middle Pleistocene-Present tectonic phase trend E-W to ESE-WNW and show a dip-slip normal sense of movement. Locally, NW-SE or even NNW-SSE structures, inherited from older phases, have been also reactivated as, for example, during the 1954 Sophades earthquake $(M=7.0)$ where oblique-slip motion occurred along ground ruptures of such direction (see lateron).

The degree of fault activity, which is expressed as the long-term average slip-rate, $S$, has been estimated for most of the active faults and this is mainly based on the amount of displacement of stratigraphic markers. When stratigraphic data are not sufficient for dating, the «freshness» of the morphotectonic features are tentatively used. All the morphological features observed along or near each of the studied faults were also classified as fault-generated morphologies or fault-related features. Numerous examples of both types were observed all over Thessaly. In the following sections, the most representative active faults of the southern and northern sectors of Thessaly are briefly described.

\subsection{Nea Anchialos Fault (fig. 3)}

The Nea Anchialos Fault is one of the more prominent tectonic features of Thessaly (fig. 1). It trends E-W and it bounds the northern margin of the Late Quaternary Almyros Basin which nowadays is partly submerged in the Pagasitikos Gulf. Pleistocene sediments and basalts are affected by normal faulting, the geometry and kinematics of which indicate N-S extension. On July 9, 1980 a morphogenic earthquake, that is a seismic event able to generate surficial deformation along the fault it activates (Caputo, 1993b), with magnitude 6.5 occurred in the area (fig. 4). The focal mechanisms, the distribution of the seismic sequence, the shape of the isoseismal map and the ground ruptures indicate that this major fault was activated during the quake (Papazachos et al., 1983). As well as geological and seismological

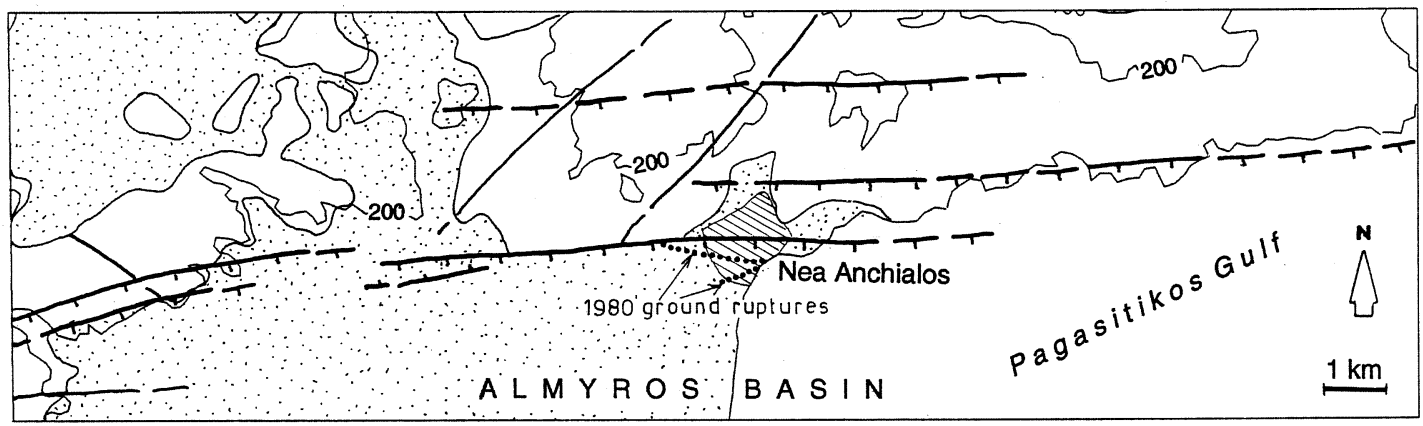

Fig. 3. Sketch map of the Nea Anchialos Fault. Topographic contours every $200 \mathrm{~m}$. Thick lines represent major Late Quaternary faults with barbs on the downthrown side. Dotted lines represent the ground ruptures which occurred during the 1980 Volos earthquake $(M=6.5)$. Dotted areas are Pleistocene-Holocene deposits and Quaternary basalts. See fig. 1 for location. Modified from Caputo (1990a). 


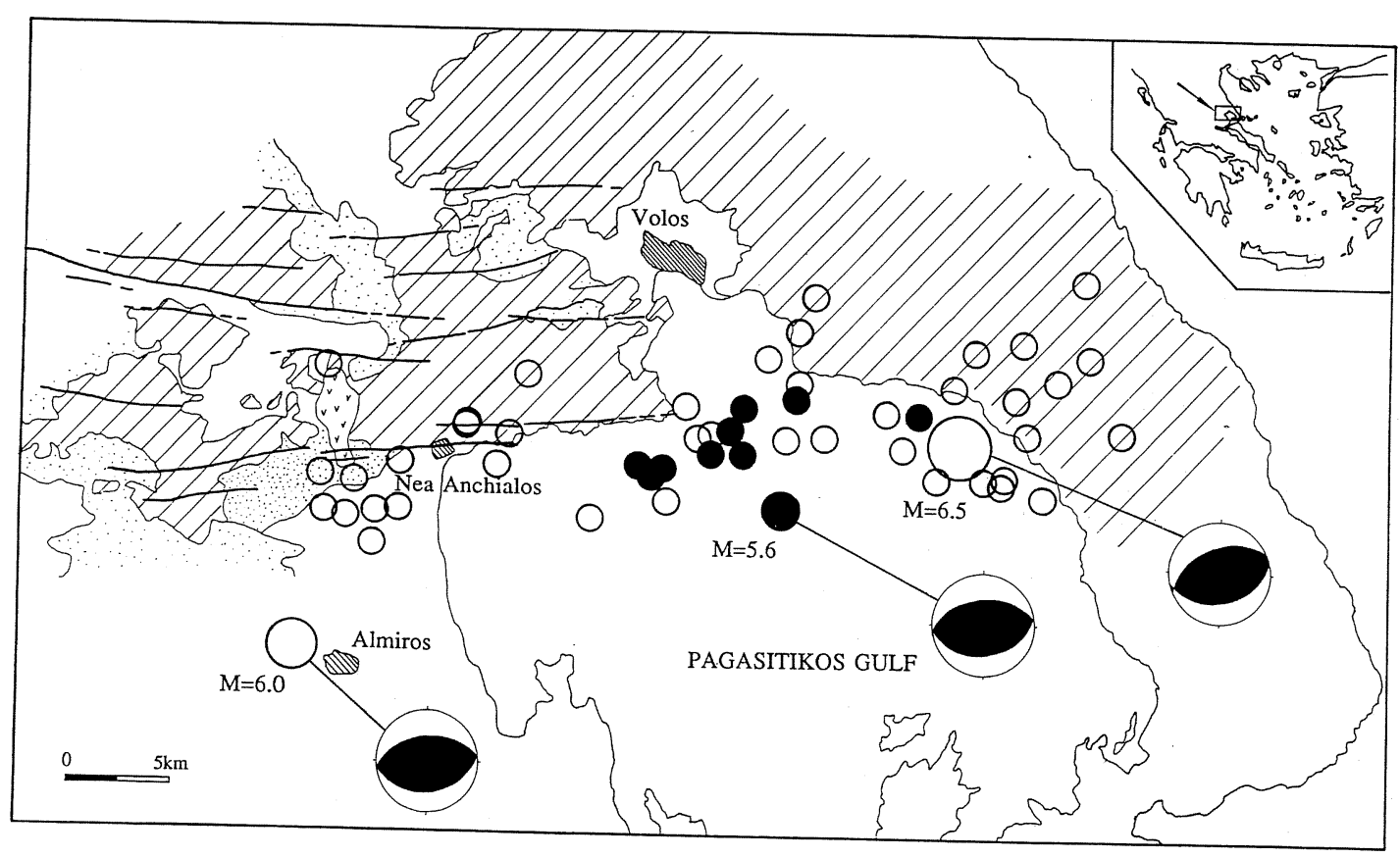

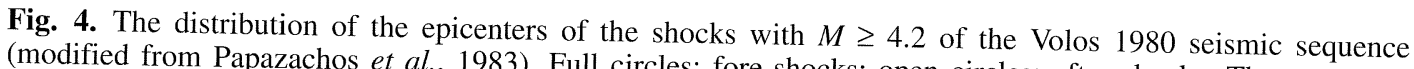
(modified from Papazachos et al., 1983). Full circles: fore-shocks; open circles: after shocks. The computed
relative focal mechanisms are shown.

data, archaeological data have also been collected in the area. A palaeochristian aqueduct crops out in the footwall block near the main escarpment along a valley which was naturally entrenched clearly after the construction of the structure (Caputo, 1990b). According to the age of the construction (3rd-4th century A.D., P. Lazarides, personal communication, 1990) and applying simple morphological criteria, the historic-time slip-rate along the fault zone was tentatively inferred (Caputo, 1990b). It amounts to $2-3 \mathrm{~mm} / \mathrm{yr}$ (class A of RGAFJ, 1992) and is comparable to the long-term sliprate estimated for geological times responsible for the genesis of the Almyros Basin (MiddleLate Quaternary).

\subsection{Righeo Fault (fig. 5)}

The Righeo Fault forms the northern border of the eastern sector of the Vasilika Basin, a
Late Quaternary narrow asymmetric graben (fig. 1). The fault seems to be a continuous structure with a total length of more than 20 $\mathrm{km}$. Deposits of Late Pleistocene age are affected by this E-W trending south-dipping structure which shows a sharp straight morphological scarp from several tens to hundreds of metres high along its length. On March 8, 1957 near the village of Velestino two earthquakes occurred seven minutes apart with magnitude 6.5 and 6.6 (Ambraseys and Jackson, 1990; or 6.5 and 6.8, according to Papazachos et al., 1982). Although no focal mechanism is available and no clear evidence of surface faulting was produced from later mapping, the distribution of the macroseismic epicenters of the main shock and of the aftershocks (Ambraseys and Jackson, 1990) strongly supports the hypothesis that the Righeo Fault was the seismogenic structure of the 1957 Velestino earthquakes (Caputo, 1990a). Though the isoseismal map inferred from macroseismic data is probably 


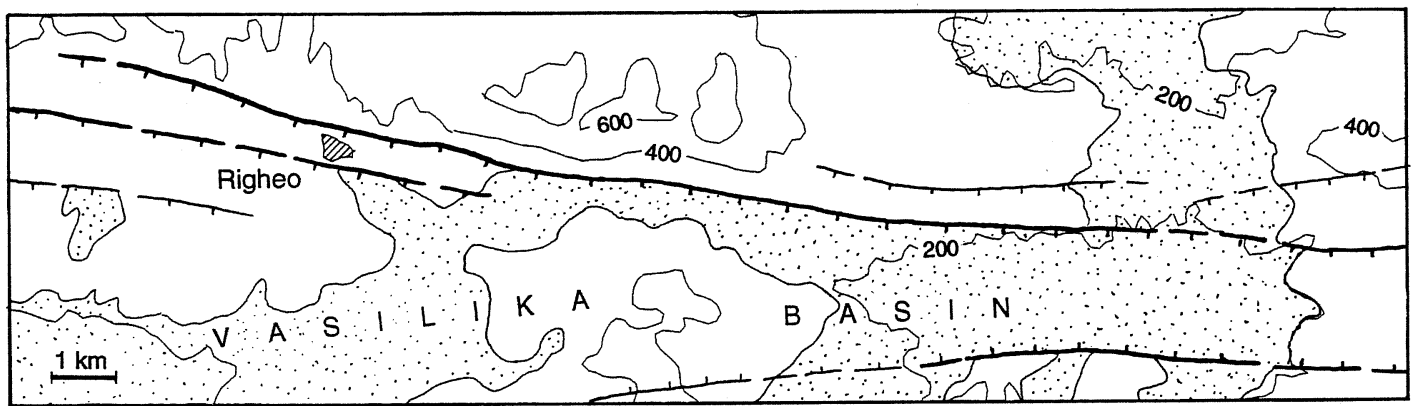

Fig. 5. Sketch map of the Righeo Fault. Topographic contours every $200 \mathrm{~m}$. Thick lines represent major Late Quaternary faults with barbs on the downthrown side. Dotted areas are Pleistocene-Holocene deposits. See fig. 1 for location. Modified from Caputo (1990a).

«cumulative» of the two earthquakes and thus doubtful, it clearly shows an E-W trending seismic structure (Papazachos et al., 1982). Although no exact slip-rate has been computed, according to morphotectonic criteria, the fault is certainly within the range of classes A or B.

\subsection{Domokos Fault System (fig. 6)}

The Domokos Fault System is a shortly segmented complex fault system bordering the southern edge of the Oligocene-Pliocene
Karditsa Basin (Western Thessaly, Caputo, 1990a). In Late Cainozoic times, the area suffered a strong brittle deformation and was severely fractured by several tectonic phases that generated the prevailing NW-SE structures. Within this inherited system, the E-W trending fault segments generated during the Late Quaternary extension, show a complex cross cutting relationship (Caputo, 1990a; Pavlides, 1993). During the 1954 Sophades earthquake, whose magnitude was 7.0 according to Papazachos et al. (1982), some of these segments were reactivated (Papastamatiou and

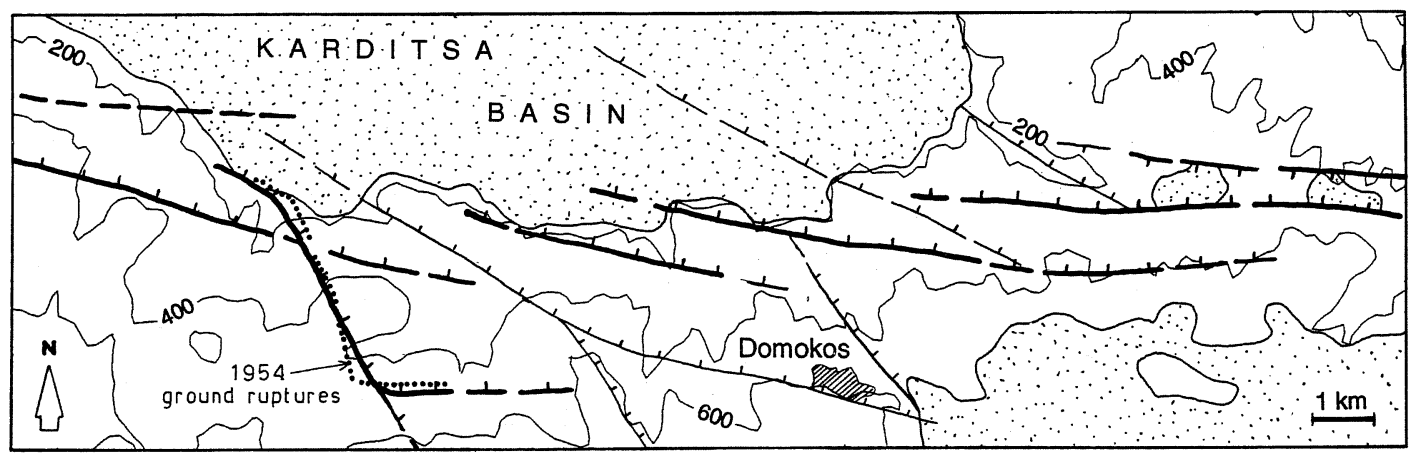

Fig. 6. Sketch map of the Domokos Fault System. Topographic contours every $200 \mathrm{~m}$. Thick lines represent major Late Quaternary faults with barbs on the downthrown side. Dotted lines represent the ground ruptures which occurred during the 1954 Sophades earthquake $(M=7.0$; modified from Papastamatiou and Mouyaris, 1986). Dotted areas are Pleistocene-Holocene deposits. See fig. 1 for location. Modified from Caputo (1990a). 
Mouyaris, 1986). Several ground ruptures occurred along both E(SE)-W(NW) and (N)NW(S)SE directions showing dip-slip and obliqueslip left-lateral motion, respectively, with maximum throws of $90 \mathrm{~cm}$. The observed kinematics are compatible with the $\mathrm{N}-\mathrm{S}$ direction of extension as obtained from neotectonic data. This is in contrast with the focal mechanism presented by McKenzie (1972) which is probably unreliable because based on short period seismic recordings. Moreover, the distribution of the epicenters (main and aftershocks) based on macroseismic data (Ambraseys and Jackson, 1990) confirms the existence at depth of an E-W trending seismogenic zone reaching the surface via inherited structures and thus generating about $30 \mathrm{~km}$ of discontinuous ground ruptures along an average $\mathrm{N} 120^{\circ} \mathrm{E}$ direction. As for the Righeo Fault, also in this case the slip-rate ranges within classes $\mathrm{A}$ or $\mathrm{B}$.

\subsection{Tyrnavos Fault (figs. 7 and 8)}

A $12 \mathrm{~km}$ long north-dipping normal fault, located in the homonymous Tyrnavos Basin (fig. 1), affects substratum rocks as well as Pliocene and Late Quaternary sediments. It is segmented in three parts with E-W and ESEWNW strikes. Detailed structural analysis demonstrates that this fault was activated and generated in response to the Middle Pleistocene-Present tectonic regime (Caputo, 1993a). Both bedrock fault scarps and fresh fault scarps in unconsolidated deposits were observed. But other fault-related morphologies such as a dammed river valley, truncated scree fans and the differential erosion of scree fans on the two sides of the fault, indicate a very young age of tectonic activity. Several stratigraphical and morphological criteria, allow an estimate of long-term slip-rates ranging between 0.14 and $0.4 \mathrm{~mm} / \mathrm{yr}^{-1}$ (Caputo, 1993a) corresponding to class B of RGAFJ (1992). According to the fault geometry and the seismogenic parameters as derived from field investigations, the characteristic earthquake magnitude of the Tyrnavos Fault is 5.8-6.1 (Caputo, 1993a), consistent with that estimated for the 1731 earthquake $(M=6.0$; Papazachos and Papazachou, 1989) and located in this region. No seismic events have been recorded more recently.

\subsection{Rodia Fault System (figs. 9 and 10)}

This is a $12-15 \mathrm{~km}$ long complex fault zone made of several segments of different directions (from NW-SE to ENE-WSW) and of probably different ages (from Pliocene to Holocene). Indeed it bounds to the north both the Pliocene Larissa Basin and the Late Quaternary Tyrnavos Basin (fig. 1). A persistent set of morphological scarps (fig. 10) affects Late Pleistocene and Holocene alluvial deposits: the parallelism, lateral continuity (several hundreds meters each), angular shape, uniformity in vertical throw (between 0.5 and $2 \mathrm{~m}$ ) and constant

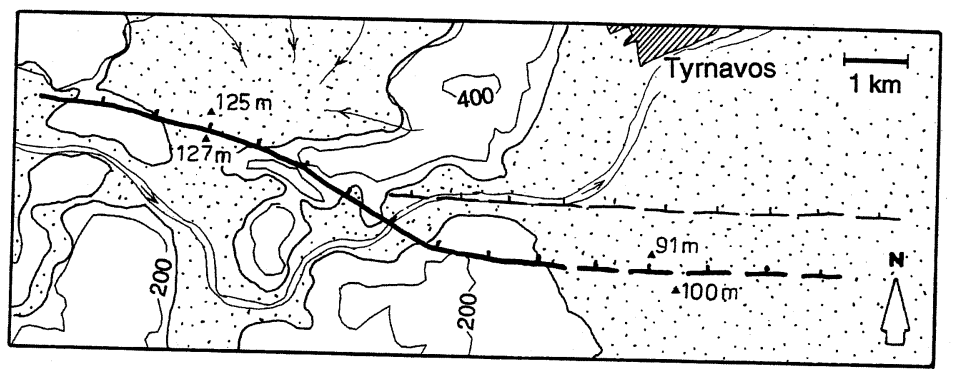

Fig. 7. Sketch map of the Tyrnavos Fault. Topographic contours every $200 \mathrm{~m}$. Local altitudes in meters above sea level. Dotted areas are Middle Pleistocene-Holocene deposits. The major stream flowing eastwards is the Titarissios River. See fig. 1 for location. Modified from Caputo (1993a). 


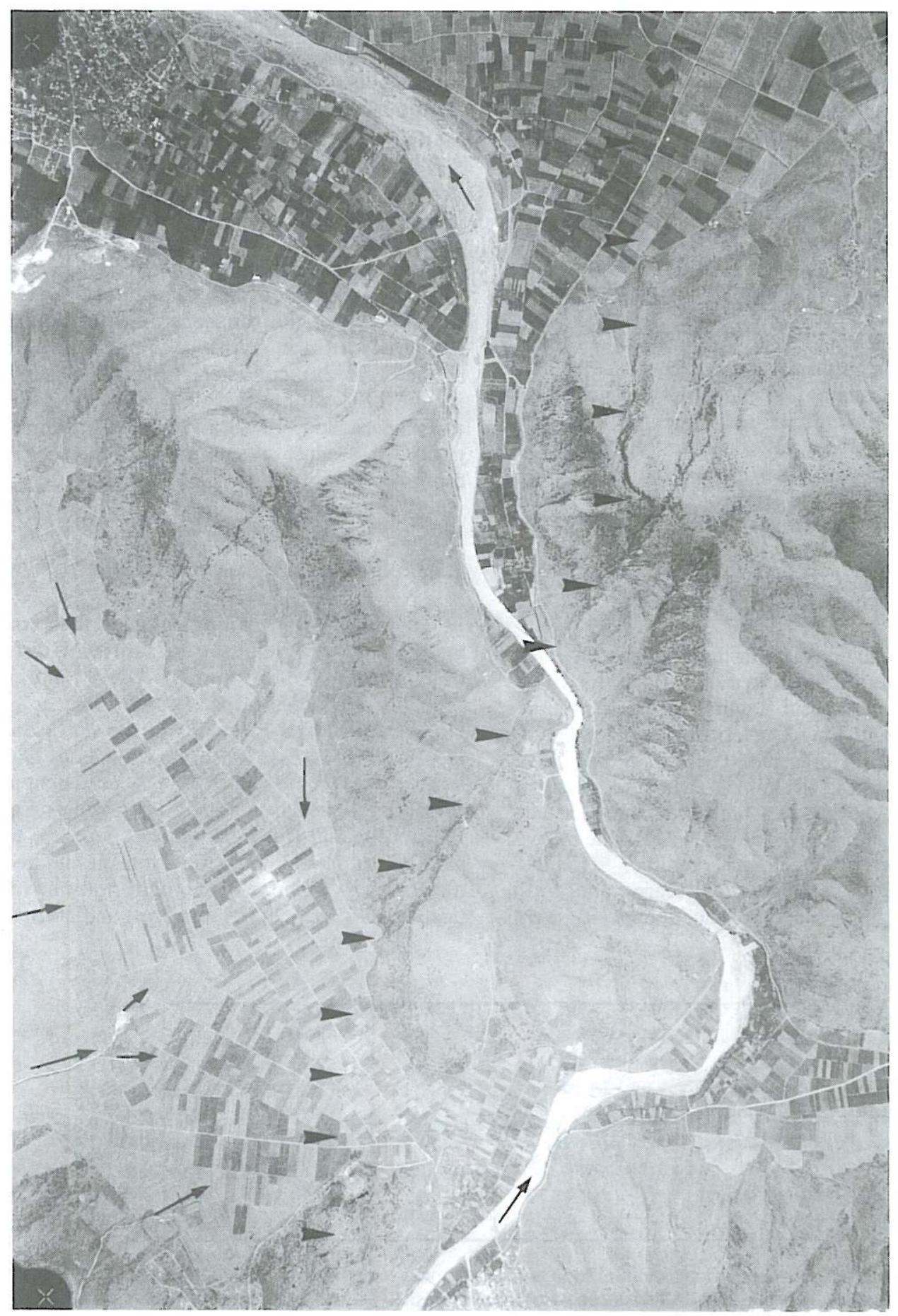

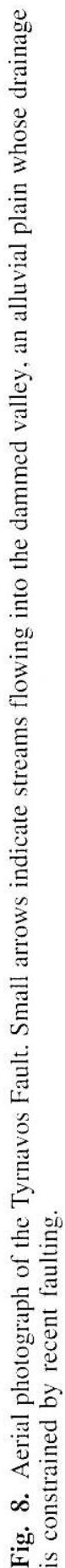




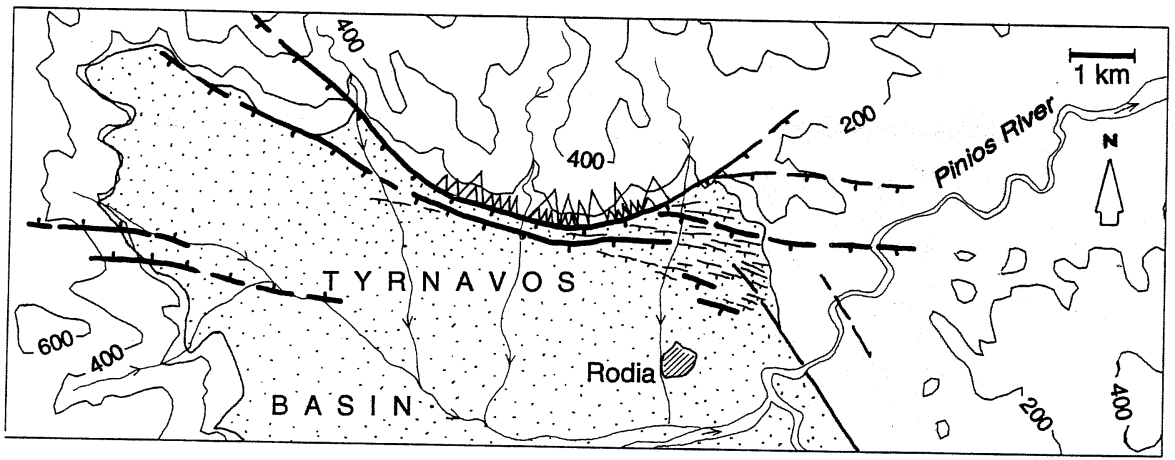

Fig. 9. Sketch map of the Rodia Fault System. Topographic contours every $200 \mathrm{~m}$. Thick lines represent major Late Quaternary faults with barbs on the downthrown side. Morphotectonic scarps are represented as thin bolocene deposits. See fig. 1 for location. Modified from Caputo (1994).
Hotted areas are Late Pleistocene-

E-W direction of these scarps reflect their tectonic origin (Caputo, 1995). A typical basinward migration of faulting was also documented where the last morphogenic faulting affects Early Holocene deposits. According to the displacement of stratigraphic horizons and to other morphotectonic criteria such as morphotectonic scarps, triangular facets (fig. 10) and the thickness of shear zones in Upper Pleistocene deposits along faults, it is possible to estimate the long-term slip-rate as $1-4 \mathrm{~mm} /$ $\mathrm{yr}^{-1}$ (class A of RGAFJ, 1992). In the central segment of the fault, up to three generations of triangular facets exist thus indicating a long period of tectonic activity of this structure. No instrumental or historical earthquakes have been located along this fault. However, two events (1766 and 1781 A.D.) with estimated magnitude of 6.3, were reported in the Northern Larissa plain (Papazachos and Papazachou, 1989). As a working hypothesis, one (or both) of these events could have occurred along this fault system.

\subsection{Gyrtoni Fault (fig. 11)}

This fault is parallel and synthetic with, but smaller than, the Rodia Fault (fig. 1). It is a $12-13 \mathrm{~km}$ long south-dipping normal fault with an ESE-WNW strike. The fault forms a 5 to $8 \mathrm{~m}$ high scarp in poorly consolidated deposits of probably late Villafranchian age (Daniela Esu, written communication, 1992). Flat lying sediments cropping out in the footwall block show features related to syn- and post-sedimentary seismic activity (i.e. seismites). The western segment of the fault sharply dissects the northern sector of the Pinios alluvial plain where the river presents a diffuse meandering, with both abandoned and active meanders, near the fault scarp. According to morphological, archaeological and historical data, the southern hanging-wall block was subsiding throughout the Late Holocene, thus confirming a very recent tectonic activity (Helly et al., 1995). A first estimate of the long-term slip-rate indicates a value below $0.1 \mathrm{~mm} / \mathrm{yr}^{-1}$. The fault thus belongs to class $\mathrm{C}$.

\subsection{Chasambali Fault System (fig. 12)}

The Chasambali Fault System comprises a set of north-dipping minor faults antithetic to the Gyrtoni Fault (fig. 1). In Late Quaternary times, these faults played a crucial role in the palaeogeographic evolution of the area (Caputo et al., 1994). They constrained the Pinios River to flow in the northern sector of the Larissa Plain which paradoxically stands at an altitude of 20 to $40 \mathrm{~m}$ higher than its southern sector 

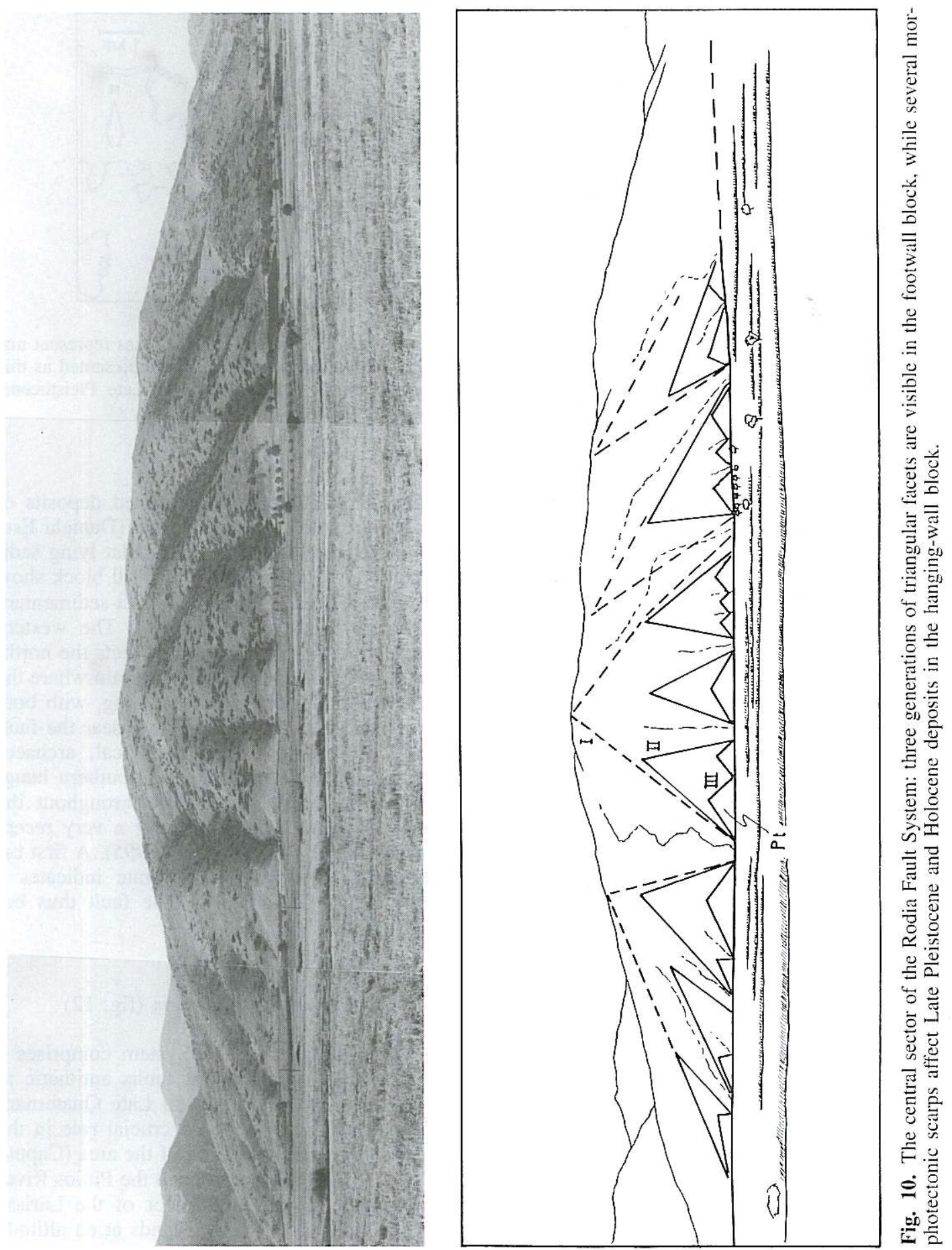


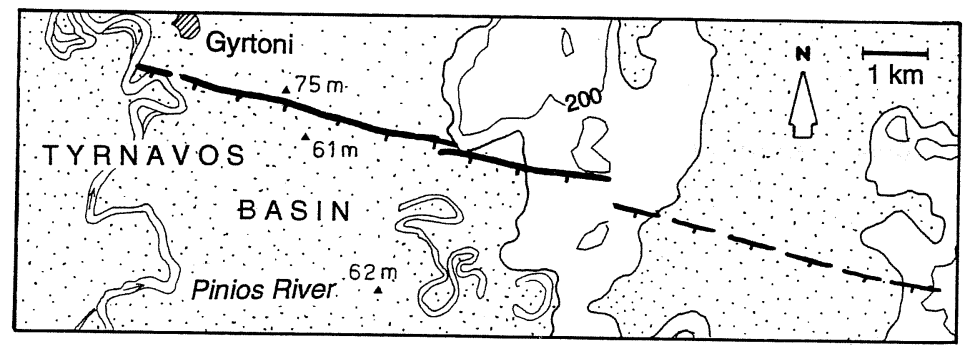

Fig. 11. Sketch map of the Gyrtoni Fault. Topographic contours every $200 \mathrm{~m}$. Local altitudes in meters above sea level. Some abandoned meanders of the Pinios River are also shown. Dotted areas are PleistoceneHolocene deposits. See fig. 1 for location. Modified from Caputo et al. (1994).

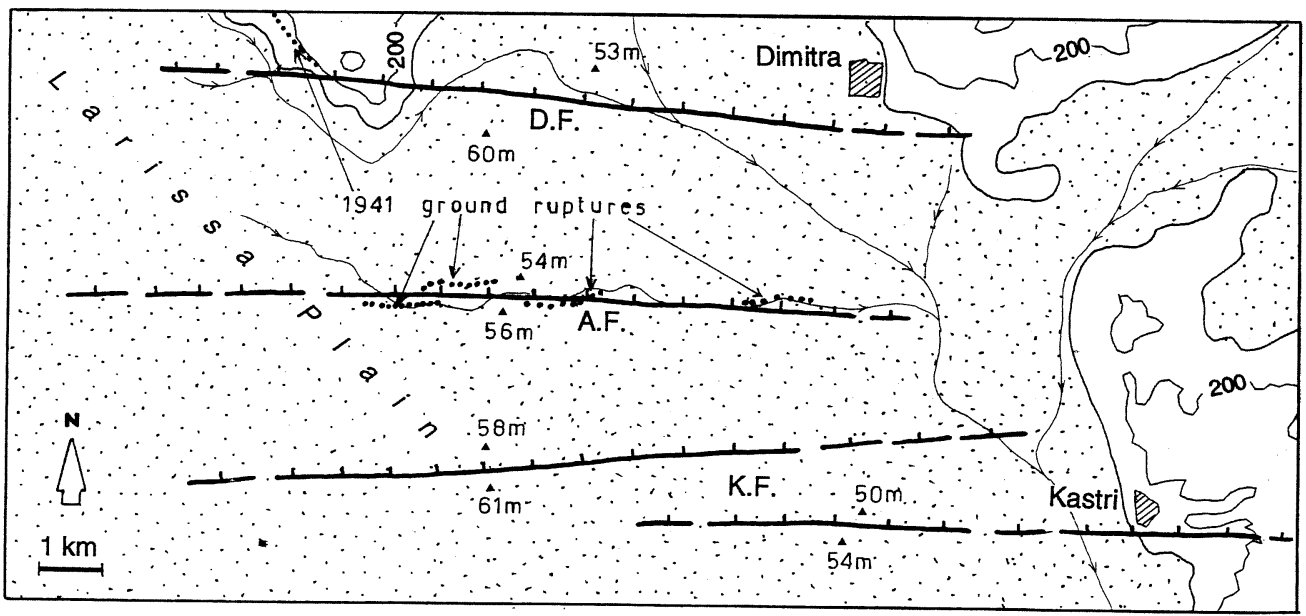

Fig. 12. Sketch map of the Chasambali Fault set. Topographic contours every $200 \mathrm{~m}$. Local altitudes in meters above sea level. Dotted lines represent the ground ruptures occurred during the 1941 Larissa earthquake $(M=6.3)$. Dotted areas are Late Pleistocene-Holocene deposits. K.F. = Kastri Fault, A.F. = Asmaki Fault, D.F. = Dimitra Fault. See fig. 1 for location. A tectonically controlled hydrographic network is evident. Modified from Caputo et al. (1994).

(ex Karla Lake). These faults affect the latest Pleistocene and Holocene deposits and their recent morphogenic activity is also confirmed by archaeological data (Helly et al., 1995). Some ground cracks several meters long and $2-3 \mathrm{~cm}$ wide recently opened along the Kastri Fault showing that very low but not instrumentally recorded seismic activity exists. The macroseismal epicentre of the 1941 Larissa earthquake $(M=6.1)$ was tentatively located in this area (Galanopoulos, 1950). In the bedrock NE of Larissa a series of ruptures striking NW-SE were reported after the earthquake and tentatively assumed to be the seismogenic fault by Ambraseys and Jackson (1990). However, numerous ground fractures also occurred along the recently recognised Asmaki Fault (Caputo et al., 1994) suggesting that one of the segments of this E-W trending fault system could have been the seismogenic structure of the 
1941 Larissa earthquake. Because the dissected topographic surface of this area is Holocene (Caputo et al., 1995), $0.1 \mathrm{~mm} / \mathrm{yr}^{-1}$ is a minimum value for the long-term slip-rate assigning the fault to class B.

\section{Discussion}

The results of the neotectonic, morphotectonic and seismotectonic research recently carried out in Thessaly, show that several Late Quaternary faults affected the region, and that for most of them a very recent tectonic activity can be demonstrated (Caputo, 1990a,b; 1993a; 1995; Caputo et al., 1994). All these active faults consist of complex shear zones and are commonly segmented. They are made of newly generated E-W trending segments but also of older inherited NW-SE trending structures. Similar multi-fractured seismogenic areas have recently been described in other regions of Greece (Pavlides, 1993).

According to the map of Late Quaternary and active faults of Thessaly (fig. 1) the fault density and distribution pattern in the northern and southern sectors does not differ significantly. Also, if we consider the important parameter of the long-term slip-rate which was estimated for most of the faults, the recent morphotectonic activity of the region seems uniform and similar for the two sectors (fig. 13).

On the other hand, from the distribution of the epicentres relative to the earthquakes of the present century (fig. 2), it is clear that only, or prevailingly, the southern structures have been

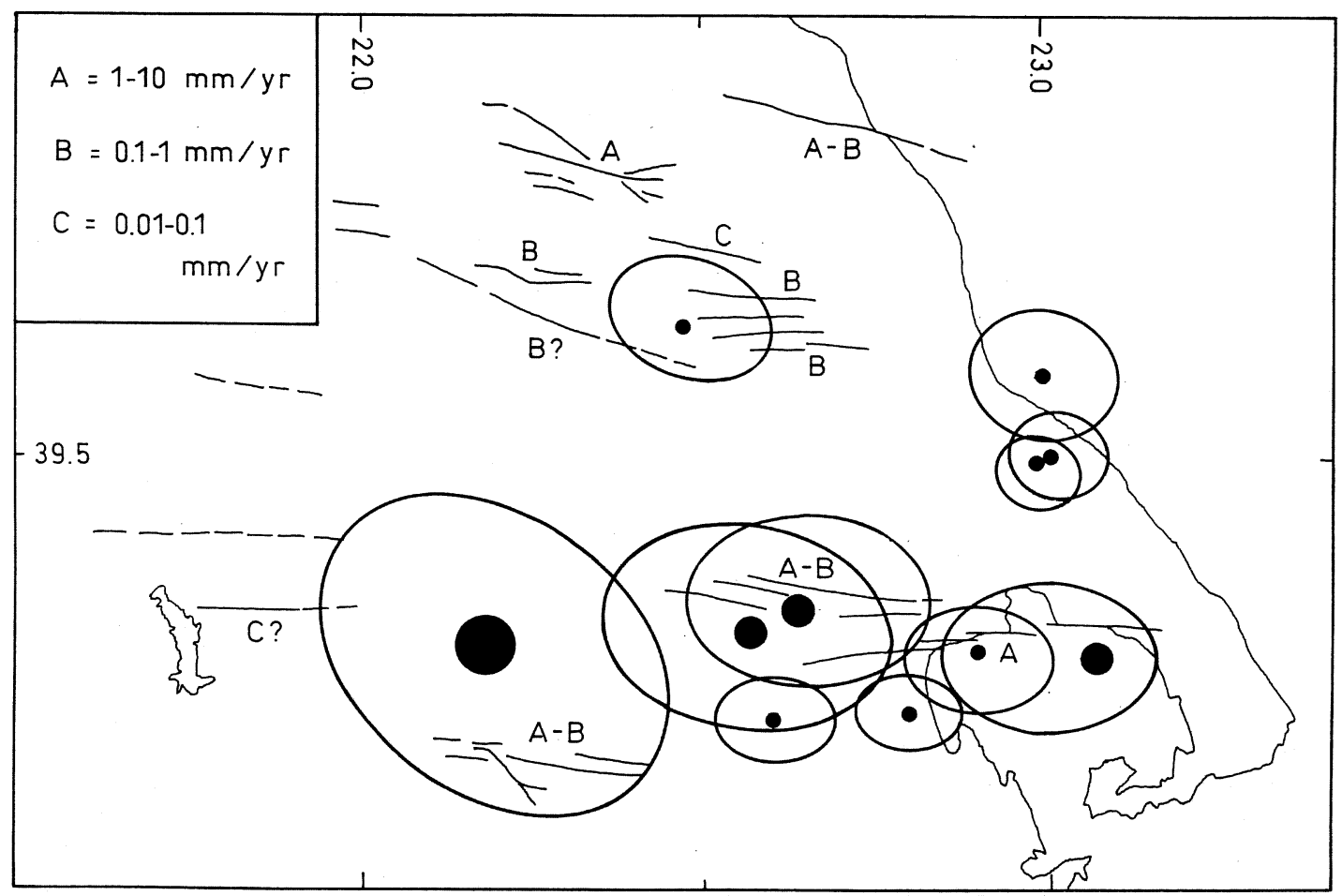

Fig. 13. Sketch map with the possible seismogenic volumes associated with the major earthquakes (full circles) which occurred during the present century. Within these volumes the tectonic stresses were probably mainly released. For the major active faults of Thessaly, the degree of activity as classified by RGAFJ (1992) is also represented. See text for discussion. 
reactivated. In particular if we take into account the major shocks which have occurred during the last decades, whose associated morphogenic faults have been identified, the same geographically N-S diversified seismic behaviour is manifest. With the exception of the 1941, Larissa earthquake $(M=6.1)$, all the seismic events with magnitude higher than 6.0 occurred in the southern sector.

As a consequence of any earthquake, the crustal volume around the hypocenter suffers a strong stress release. In fig. 13, the volumes associated to the major earthquakes which occurred in Thessaly during this century are tentatively represented assuming they are roughly proportional to the magnitude, they are related to the geometric parameters of the associated faults as well as to the ground ruptures which occurred and the distribution of the aftershocks. Similar maps based on the degree VIII isoseismals and the rupture zones (Papadopoulos, 1992) are comparable to the proposed one.

In conclusion, it is very likely that the recurrence time of seismic events is of the order of few hundred years. This is a direct consequence of, first, the small size of the faults (generally less than $20 \mathrm{~km}$ ), second, their intrinsic capacity to trigger earthquakes of moderate to small magnitude and, third, the relatively high slip-rates (classes A and B of many faults). Accordingly, and from the distribution of active faults, the hypothesis of a large seismic gap in the northern sector of Thessaly seems confirmed.

Work is still in progress to perform the third step of the project (i.e. palaeoseismicity of Thessaly). Several potential sites have been recognised along most of the previously described active faults where the digging of exploratory trenches, microstratigraphic studies and sampling for radiochronological dating will be carried out. Although the data already collected and analysed in the present research support the proposed conclusions, this new investigating approach will enhance our knowledge concerning the Late Holocene seismic activity along these faults and potentially will enable us to estimate a short-term slip-rate and a more precise return period for morphogenic earthquakes.

In the northern sector of Thessaly, further complementary research will certainly be useful. In this regard, geodetic surveying of these structures by classical surface techniques or by advanced satellite supported methodologies (GPS, VLBI, etc.) and the installation of a local network of seismographs for recording the microseismicity of the area will be extremely useful and welcome. Nonetheless, from the present research, solely based on geological (structural and morphotectonic) data, it is clear that the northern tectonic structures induce a seismic hazard for the area much higher than previously supposed. If we consider also the dense population in the surrounding region, particularly being so close to the city of Larissa, and the soft materials on which most of the buildings in this area are constructed, the northern Thessaly area is likely to have a high potential seismic risk.

\section{Acknowledgements}

Thanks to Spyros Pavlides for the numerous discussions and to Michele Caputo for many useful comments. Reviewing by Richard Collier, Mustapha Meghraoui and Daniela Pantosti has been appreciated. Daniela Esu is also warmly thanked for the paleontological datings along the Gyrtoni fault. The research was supported by several sources among which are the Italian Ministry of the University (personal grants and funds to Mario Boccaletti), the European Community (Stimulation Action Project, contract No. SC1*0056), the Italian National Council of Research (CNR-Centro di Geologia of Florence) and NATO.

\section{REFERENCES}

Ambraseys, N.N. and J.A. JACKSON (1990): Seismicity and associated strain of Central Greece between 1890 and 1988, Geophys. J. Int., 101, 663-708.

ANGELIER, J. (1977): Sur l'évolution tectonique depuis le Miocène supérieur d'un arc insulaire Méditerranéen: l'Arc Ègéen, Rev. Géogr. Phys. Géol. Dyn., 19 (3), 271-294. 
Angelier, J. (1979): Néotectonique de l'arc égéen, Soc. Géol. Nord Spéc. Publ., 3, 1-418.

Angelier, J., J.F. Dumont, H. Karamanderesi, A. PoisSON, S. SIMSEK and S. UYSAL (1981): Analyses of fault mechanisms and expansion of Southwestern Anatolia since the Late Miocene, Tectonophysics, $\mathbf{7 5}$, T1-T9.

Aubouin, J. (1959): Contribution à l'étude géologique de la Grèce Septentrional: les confins de l'Epire et de la Thessalie, Ann. Géol. Pays Hellen., 10, 1-525.

Bolt, B.A. (1993): Earthquakes (Freeman \& C., New York), pp. 331

BRUNN, J.H. (1956): Contribution à l'étude géologique du Pinde Septentrional et d'une partie de la Macédoine Occidentale, Ann. Géol. Pays Hellen., 7, 1-358.

CAPUTO, R. (1990a): Geological and Structural Study of the Recent and Active Brittle Deformation of the Neogene-Quaternary Basins of Thessaly (Central Greece), Ph.D. thesis, Scientific Annals, Aristotle University of Thessaloniki, Thessaloniki, 12, pp. 252.

CAPuTO, R. (1990b): Recent tectonics along the active Nea Anchialos Fault zone (Central Greece), edited by M.Y. SAVASÇIN and A.H. ERONAT, in Proceedings of the International Earth Sciences Congress on Aegean Regions, October 1-5, 1990, Izmir, II, 13-27.

CAputo, R. (1993a): Morphotectonics and kinematics along the Tyrnavos Fault, Northern Larissa Plain, mainland Greece, Z. Geomorphol., Suppl., 94, 167-185.

CAPUTO, R. (1993b): Morphogenic earthquakes: a proposal, Bull. INQUA Neotectonics Commission, 16, 24.

CAPUTO, R. (1995): The Rodia Fault: an active complex shear zone (Larissa Basin, Central Greece), 6th Congr. Geol. Soc. Greece, Athens, May 25-27, 1992, Bull. Geol. Soc. Greece, 28 (1), 447-456.

CAPuto, R. and S. PAvlides (1993): Late Cainozoic geodynamic evolution of Thessaly and surroundings (Central-Northern Greece), Tectonophysics, 223, 339-362.

Caputo, R., J.P. Bravard and B. Helly (1994): A tectosedimentary model for the Pliocene-Quaternary evolution of the Larissa Plain (Eastern Thessaly, Greece), Geodinamica Acta, 7 (2), 57-85.

Celet, P. (1962): Contribution à l'étude géologique du Parnasse-Kiona et d'une partie des régions méridionales de la Grèce continentale, Ann. Géol. Pays Hellen., 13, 1-446.

Comninakis, P.E. and B.C. PAPAZAChos (1982): A catalogue of historical earthquakes in Greece and surrounding area. 479 B.C.-1900, Publ. Geophys. Lab. Univ. Thessaloniki, n. 5, Thessaloniki.

Comninakis, P.E. and B.C. PAPAZAChos (1986): A catalogue of earthquakes in Greece and the surrounding area for the period 1901-1985, Publ. Geophys. Lab. Univ. Thessaloniki, n. 1, Thessaloniki.

Dercourt, J. (1964): Contribution à l'étude géologique d'une secteur du Peloponnese Septentrional, Ann. Géol. Pays Hellen., 15, 1-418.

Galanopoulos, A.G. (1950): Die beiden schadenbringenden Beben von Larissa aus den Jahren 1892 und 1941, Sonderdruck aus «Gerlands Beitrage zur Geophysik», 62, Heft 1, 27-38, Akademische Verlagsgesellschaft Geest und Portig K.-G., Leipzig C1.

GODFriauX, I. (1968): Etude géologique de la région de l'Olympe (Grèce), Ann. Géol. Pays Hellen., 19, 1-725.

Helly, B., J.-P. Bravard and R. Caputo (1995): La Plaine orientale de Thessalie (Grèce): mobilité des paysages historiques et évolution tecto-sédimentaire, Seminario Internazionale: L'evoluzione dell'ambiente fisico nel periodo storico nell'area circum-Mediterranea, Ravello, June 5-8, 1993, PACT, Journal of the European Study Group on Physical, Chemical, Biological and Mathematical Techniques Applied to Archaeology, 21 (in press).

LemeILle, F. (1977): Ètudes Neotectoniques en Grèce Centrale Nord-Orientale (Eubée Centrale, Attique, Béotie, Locride) et dans les Sporades du Nord (ile de Skiros), These 3ème cycle, Université de Paris XI, Paris, pp. 173.

McCanN, W.R., S.P. Nishenko and L.R. Sykes (1979): Seismic gaps and plate tectonics: seismic potential for major plate boundaries, PAGEOPH., 117, 1082-1147.

MCKenzIE, D.P. (1972): Active tectonics of the Mediterranean region, Geophys. J.R. Astron. Soc., 30, 109-185.

Mercier, J.-L. (1968): Étude géologique des zones internes des Hellénides en Macédoine centrale (Grèce), Ann. Géol. Pays Hellen., 20, 1-472.

MERCIER, J.-L. (1981): Extensional-compressional tectonics associated with the Aegean Arc: comparison with the Andean Cordillera of South Peru-North Bolivia, Phil. Trans. R. Soc. London, ser. A, 300, 337-355.

Mercier, J.-L., N. Delibasis, A. Gauthier, J. Jarrige, F. Lemeille, H. Philip, M. Sebrier and D. Sorel (1979): La néotectonique de l'Arc Egéen, Rev. Géol. Dyn. Géogr. Phys., 21, 67-92.

Mercier, J.-L., D. Sorel and K. Simeakis (1987): Changes in the state of stress in the overriding plate of a subduction zone: the Aegean arc from Pliocene to the present, Ann. Tectonicae, 1 (1), 20-39.

PAPADOPOUlos, G.A. (1992): Rupture zones of strong earthquakes in the Thessalia region, Central Greece, in Proceedings of the XXIII General Assembly European Seismological Commission, Prague, Sept. 7-12, 1992, 2, 337-340.

Papastamatiou, D. and N. Mouyaris (1986): The earthquake of April 30, 1954, in Sophades (Central Greece), Geophys. J. R. Astron. Soc. London, 87, 885-895.

PAPAZACHOS, B.C. and P.E. ComnINAKIS (1978): Geotectonic significance of the deep seismic zones in the Aegean area, Second Intern. Scient. Conf., Thera and the World, Santorini, August 1978, 121-129.

Papazachos, B.C., P.E. Comninakis, P.M. HatzidimiTriou, E.C. Kiriakidis, A.A. Kiratzi, D.G. PanAgiotopoulos, E.E. Papadimitriou, Ch.A. PapaioanNOU and S. PAVLIDES (1982): Atlas of isoseismal maps for earthquakes in Greece 1902-1981, Publ. Geophysical Lab. University of Thessaloniki, Thessaloniki, n. 4, pp. 126.

Papazachos, B.C., D.G. Panagiotopoulos, T.M. Tsapanos, D.M. Mountrakis and G.C. Dimopoulos (1983): A study of the 1980 summer seismic sequence in the Magnesia region of Central Greece, Geophys. J. R. Astron. Soc. London, 75, 155-168.

PAPAZACHOS, B., A. KIrATZi and E. PAPAdimitriou (1991): Regional focal mechanisms for earthquakes in 
the Aegean area, Pure Appl. Geophys., 136 (4), 405420.

Papazachos, B. and K. PApazachou (1989): I Sismi tis Elladas (The earthquakes of Greece), Ziti, Thessaloniki (in Greek), pp. 356.

Paquin, C., C. Froidevaux, J. Bloyet, Y. Ricard and C. ANGelidis (1982): Tectonic stresses on the mainland of Greece: in situ measurements by overcoring, Tectonophysics, 86, 17-26.

PAvlides, S.B. (1993): Active faulting in multi-fractured seismogenic areas: examples from Greece, Z. fur Geomorphol., Suppl., 94, 57-72.

Pavlides, S.B. and D.M. Mountrakis (1987): Extensional tectonics of Northwestern Macedonia, Greece, since the Late Miocene, J. Struct. Geol., 9 (4), 385392.

Pegoraro, O. (1972): Application de la Microtectonique à une Ėtude de Neotectonique. Le Golfe Maliaque (Grèce Centrale), These 3ème Cycle, Université du Languedoc, Montpellier, pp. 39.
Research Group for Active Faults of JaPAN (1992): Maps of Active Faults in Japan with Explanatory Test (University of Tokyo Press), pp. 73.

SOREL, D. (1989): L'évolution Structurale de la Grèce Nord-Occidentale Depuis le Miocène dans le Cadre Géodynamique de l'Arc Egéen, Thèse d'Etat, Universitè de Paris XI, Paris, pp. 305.

SyKES, L.R. and S.P. NisHENKo (1984): Probabilities of occurrence of large plate ruptiring earthquakes for the San Andres, San Jacinto, and Imperial faults, California, 1983-2003, J. Geophys. Res., 89 (B7), 59055927.

TAYMAZ, T., J. JACKSON and D. MCKenZIE (1991): Active tectonics of the North and Central Aegean Seam, Geophys. J.R. Astron. Soc., 106, 443-490.

(received March 18, 1994; accepted October 18, 1994) 